\title{
Plant wealth of a sacred grove: Mallur Gutta, Telangana state, India
}

This article was published in the following Dove Press journal:

International Journal of General Medicine

26 October 2016

Number of times this article has been viewed

\section{Sateesh Suthari' \\ Ramesh Kandagalta ${ }^{2}$ \\ Ajmeera Ragan ${ }^{2}$ \\ Vatsavaya S Raju ${ }^{2}$}

'Department of Plant Sciences, School of Life Sciences, University of Hyderabad, Hyderabad, ${ }^{2}$ Plant Systematics Laboratory, Department of Botany, Kakatiya University, Warangal, India
Correspondence: Vatsavaya S Raju Department of Botany, Kakatiya University, Warangal 506 009, Telangana, India

Tel +9l 8702438238

Email rajuvatsavaya@gmail.com
Abstract: The Mallur Gutta (Hill) of Warangal district in Telangana state, India, reputed as a habitat for medicinal plants, was inventoried from 2009 to 2015 for its plant wealth through the traditional knowledge of the local people. The Hindu temples of Lord Sri Laxminarasimha Swamy and Lord Hanuman, and the ethnic worship of mahua trees indicated it was a sacred grove which was selected as a Medicinal Plants Conservation Area. The exploration of Mallur Gutta resulted in the enumeration and documentation of plant wealth representing 470 species of 318 genera pertaining to 95 families of vascular plants. The importance of the grove as the residence for many rare or medicinal species in the state of Telangana is documented. The plant diversity is analyzed in terms of growth and life forms which indicate the prevailing microclimate, ecological opportunities and the species richness. The ecological services rendered by the Mallur Gutta forest ecosystem are documented to study how the great majority of the species are used by the ethnic and nonethnic people, and also the pilgrims who visit the shrine for its serenity. The study also identified two major threats to the conservation of hill ecosystem and the archeological site: 1) biotic pressure (the ever-increasing pilgrims, grazing by cattle, goat and sheep, the development activities taken up for the pilgrims, nondegradable litter thrown, collection of medicinal plants and widening of the pathway to the Chintamani perennial stream - the trampling and alien plant invasions of the marsh sustaining the stream); and 2) the potential for fire spreading from burning the litter. The study suggests the need to initiate remedial measures toward ecosystem recovery through fencing the natural vegetation, maintaining a fire line, and restricting the movement of people and domesticated animals on the hill top.

Keywords: India, plant diversity, montane ecosystem, sacred grove, Koyas, traditional knowledge, conservation

\section{Introduction}

The plant wealth of an area is its natural resource and knowledge source. Knowing about the vegetation type and the flora of a natural habitat is of immense ethnic, economic and scientific use to its inhabitants. The survival of human beings and their pet animals depends upon the availability of living resource like food, fodder and fiber connected with other living organisms (food chain) and the life-supporting abiotic elements. Documenting all the plant species in an area and their uses based on the traditional knowledge is like knowing the economic development of its people.

The Indian subcontinent is known for its biological diversity. The Republic of India is one of the 17 megadiverse countries. ${ }^{1}$ The Warangal district, located in the northern Telangana of India, is rich in biota spread in North and South Forest Divisions 
useful for the economic development of the dependent ethnic communities. ${ }^{2,3}$ The district has forests rich in timber and tendu leaf providing a good revenue to the Telangana state government. These forests were explored previously by many botanists for their flora, ethnomedicinal plants and other non-timber forest products (NTFPs). ${ }^{2,4-10}$ The first floristic account of the Warangal district was that of Pakhal Reserve Forest in the South Division during the period 1960-1963. ${ }^{5}$ The study reported 254 species belonging to 198 genera of 70 families. The doctoral thesis of Reddy ${ }^{2}$ documented 1223 vascular plant species (1208 Magnoliophyta +15 Pteridophyta). Of these, 943 were dicots (Magnoliopsida), and 265 monocots (Lililopsida), and these included 268 cultivated species. Later, Reddy and Raju ${ }^{6,7}$ reported several additions to the known flora of the district.

No specific publication on the flora of the Mallur hill is available except the collection of 20 species mentioned in the floristic study of the district. ${ }^{2}$ There is no mention of Mallur as a sacred grove in the publication Sacred and Protected Groves of Andhra Pradesh. ${ }^{11}$ In the survey of medicinal plants for establishing Medicinal Plants Conservation Areas (MPCAs), Mallur, with its ethnomedicinal plant wealth, emerged as the number one site in the district. Consequently, it was declared as an MPCA in 2000, and an arch forming the entrance to the sacred grove (Figure 1A) was erected at the foothills. ${ }^{12}$ And, a study made on intracultural cognizance of ethnic people in Eturnagaram Wildlife Sanctuary in the district $^{3}$ established the plant resource base existing outside the sanctuary area. ${ }^{3}$ Accordingly, we were prompted to study the vegetation and gather field-based ethnic and folklore information from Mallur hill range. Such an attempt was felt necessary and urgent in view of the fast developments taking place under the pressure of the increased number of pilgrims due to propaganda, ecotourism and Pushkaralu (a holy dip in the waters of the River Godavari near Mallur Gutta once in 12 years, eg, 2015, 2027), and also in view of the accelerated deforestation being carried out in the name of temple development, while the Vana Samrakshana Samithi (VSS, a forest protection forum) initiated by the State Forest Department under Joint Forest Management is defunct. A detailed floristic study covering the utilization pattern of plant resources (medicine, food, forage, fiber, fuel and such other NTFPs) was taken up with the twin objectives of documenting the plant species and their traditional uses, and utilizing such data for assessing aspects like the future vegetation change and resource depletion caused by anthropogenic activity.

\section{The sacred grove}

A sacred grove is a protected area where the natural vegetation patch is present and is protected by the local communities considering it as the abode of their ancestral deities or spirits. The International Union for Conservation of Nature and Natural Resources (IUCN) considers the sacred groves as sacred natural sites, classified as "the natural areas of special spiritual significance to peoples and communities which include the natural areas recognized as sacred by the indigenous and traditional people as well as natural areas recognized by institutionalized religious faiths as the places of worship and remembrance". ${ }^{13}$ Malhotra et $\mathrm{al}^{14}$ listed 13,720 sacred groves in India. The World Wide Fund for NatureAndhra Pradesh ${ }^{11}$ documented 65 sacred groves in the districts of Telangana (Adilabad 2, Hyderabad 13, Karimnagar 4, Khammam 4, Mahabubnagar 9, Medak 4, Nalgonda 9, Nizamabad 7, Ranga Reddy 10 and Warangal 3).

\section{Historical hierarchy}

In the proximity of the tiny village Mallur exists the small hill range called Mallur Gutta (Gutta means hill in the local dialect). It is spread over 1500 ha and is considered by the local people as a habitat for valuable medicinal plants useful for their primary health care. The ancient temple of Lord Lakshminarasimha Swamy was built in a strategic and secluded locale of the hill. The temple is famous for its swayambhu (self-formed) deity (Figure 1D). It was stated to be constructed by the Chola Emperors during the period 1010-1200 (perhaps, under Rajaraja I and II). And, in the hills, there are several of prehistoric megalithic dolmens (the burial sites in hundreds falling in eight lines, as per the chief priest Kainkaryam Raghava Chary) and a shila shasanam (stone inscription) with 48 letters in the Devanagari language. Hundreds of pilgrims visit the temple every Saturday; about 50,000 pilgrims from the state and the neighboring states like Chattisgarh, Andhra Pradesh, Maharashtra and Madhya Pradesh throng the temple in May to participate in the annual celebration called Vasanthothsav. The "Chintamani" waterfall (a natural stream) is another attraction (Figure 1G). It is the perennial source of water, and the people conceive this water as sacred; they use it for bathing and also take it home in bottles.

The Rapid Assessment Survey of medicinal plants conducted during 1999-2000 in collaboration with the local think tanks (from Kakatiya University and Ayurvedic College), the State Forest Department and the Environment Protection Training and Research Institute under the United Nations 

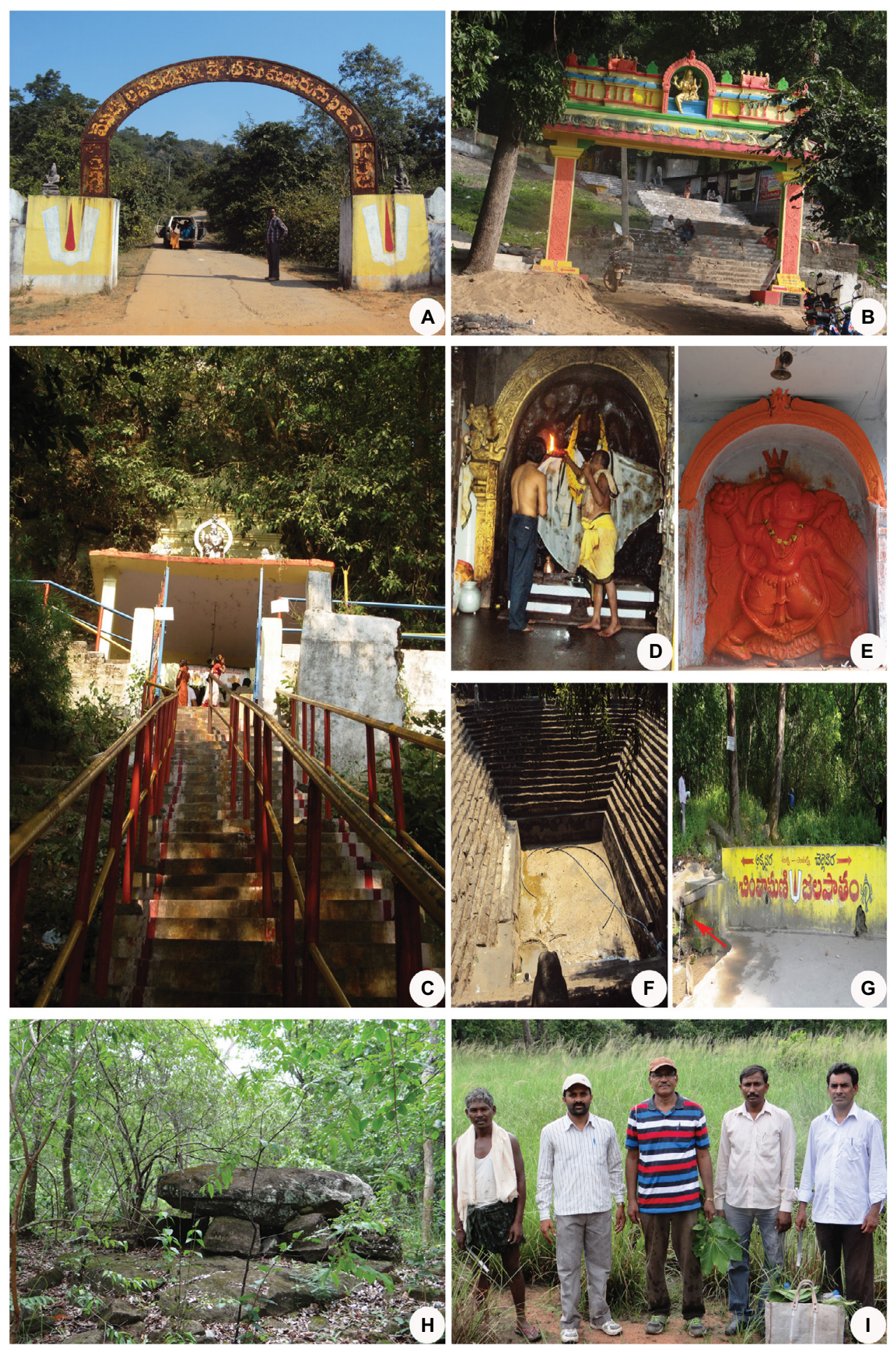

Figure I Archeological, prehistoric and natural sites on Mallur Gutta. (A) Medicinal Plants Conservation Area arch at entrance to the temple. (B) Temple arch. (C) Steps to temple. (D) Sanctum sanctorum. (E) Unique Hanuman statue, guarding the Mallur Gutta and the temple god. (F) Kolanu [tank], dried now. (G) Chintamani stream, now run through a pipe for drinking (arrow). (H) Prehistoric site. (I) Plant exploration team with one of the ethnic resource persons.

Development Programme-Ministry of Environment and Forests Project showed the Mallur hill tract of the Warangal district rich in medicinal plant diversity to be selected as one of the two MPCAs in the Telangana region. The Mallur MPCA was declared with an area of 197.97 ha.

\section{Study area}

The study area, Mallur Gutta, lies on the southwest bank of the River Godavari at $18^{\circ} 12^{\prime} 03.43^{\prime \prime} \mathrm{N}$ and $80^{\circ} 34^{\prime} 24.17^{\prime \prime} \mathrm{E}$, with an altitude of $95 \mathrm{~m}$ (Figure 2). It is located in the Mangapet Reserve Forest of the North Forest Division in the Warangal 

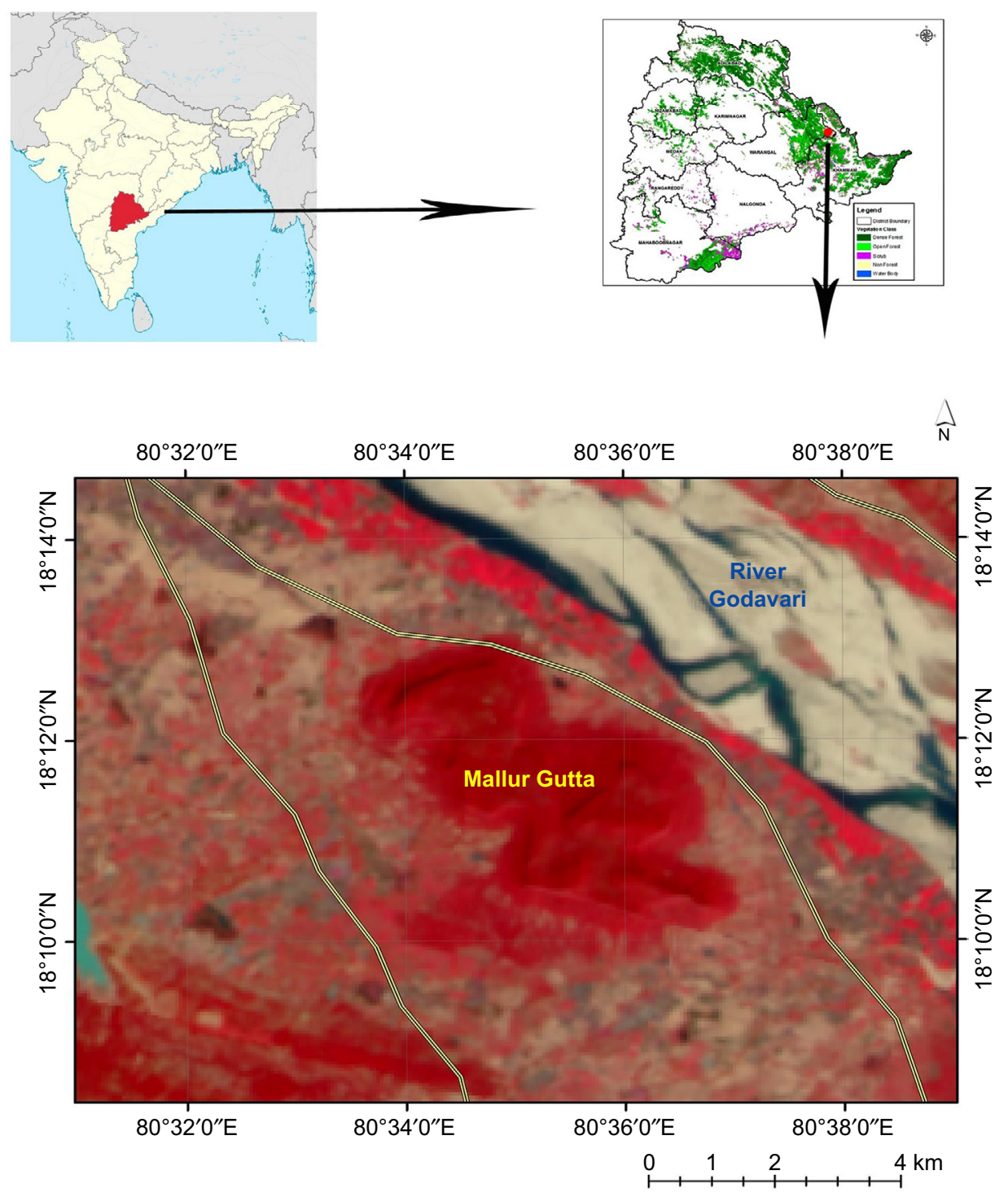

Figure 2 The study area: Mallur Gutta.

circle, at a distance of $125 \mathrm{~km}$ away from district headquarters. The longitudinal profile of the Godavari river shows distinct geomorphic or topographic domains marked by the Deccan Upland, the Precambrian granitic-fractured lowland and the linear crustal structures of the Pranahita-Godavari Rift Valley Basin. ${ }^{15}$

\section{Vegetation, soil and climate}

The surrounding area of the Mallur hill range is rich in plant diversity and shows varying microclimate of moist deciduous trees near the temple ${ }^{8}$ and of the dry deciduous forest around it (Figure 3) interspersed with grasslands (Figure 4A).

\section{Ethnic people: the Koyas (Dorla Koitur)}

The Koyas are the southernmost section of the great Gond race of central India (Gondwana). The population of this scheduled tribe is largely, though not exclusively, concentrated in Telangana and makes up the majority of the tribal population in the agency areas in the districts of Karimnagar, Warangal and Khammam, along the River Godavari. Like the Gonds of Adilabad district, they lost much of their prime land, which they cultivated with ploughs and bullocks, and are largely reduced to the position of tenants and agricultural laborers. The process of detribalization has progressed further among the Koyas than among any other Gond tribe. Their occupational or territorial realms divide the Koyas into six subgroups, viz. 1) Gotte Koya - who dance with a bison horn on head and dress like Marias; 2) Manne Koya - who inhabit secluded forest areas; 3) Gampa Koya - who make baskets (Gampalu in Telugu); 4) Warre Koya (warre means wild buffalo; bison) - who do not engage themselves in settled agriculture but live in the jungle as hunter-gatherers 

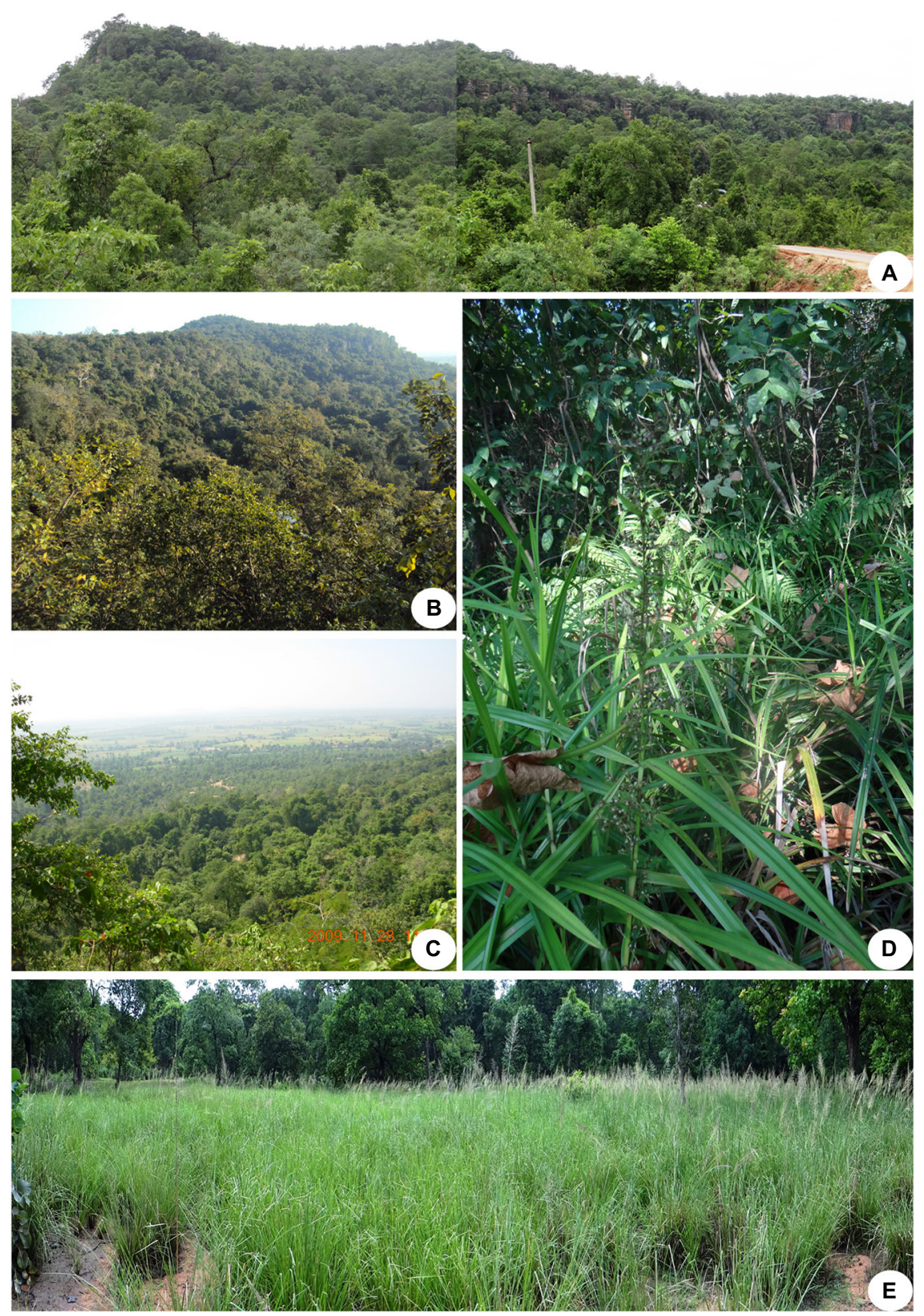

Figure 3 Mallur Gutta. (A) Landscape at the beginning of the hill. (B) Forest cover at the far end of the hill. (C) Valley on southwestern side. (D) Forest undergrowth (marsh) near Chintamani waterfall. (E) Shallow pond on hill top with dominant Chrysopogon zizanioides.

eating roots/tubers, fruits, etc.; 5) Bunka Koya - the civilized people among the Koyas who live in plains and take up settled farming; 6) Dora Koya - they are Raja Gonds and call themselves Dorlasattam (Lord Groups). The first four subgroups still speak the Gondi dialect, whereas the last two largely lost their own language and speak Telugu of their Hindu neighbors. ${ }^{17}$

\section{Materials and methods}

The field trips were conducted in the study area first under Vegetation Carbon Pool Project (2009-2012) and later under the University Grants Commission Major Project (October 2012 to July 2015), covering all the seasons of a year. The voucher specimens collected were processed and preserved at the Kakatiya University Herbarium, Warangal, for reference. ${ }^{18}$ The plant species were identified using the current floras and e-floras, and the nomenclature is as per www. theplantlist.org and www.ipni.org. The ethnobotanical data were gathered through household surveys, questionnaires and semi-structured and open-ended interviews. The interviews included informants of both genders and of age group 30-60 years of the Koya community and the non-tribes. 

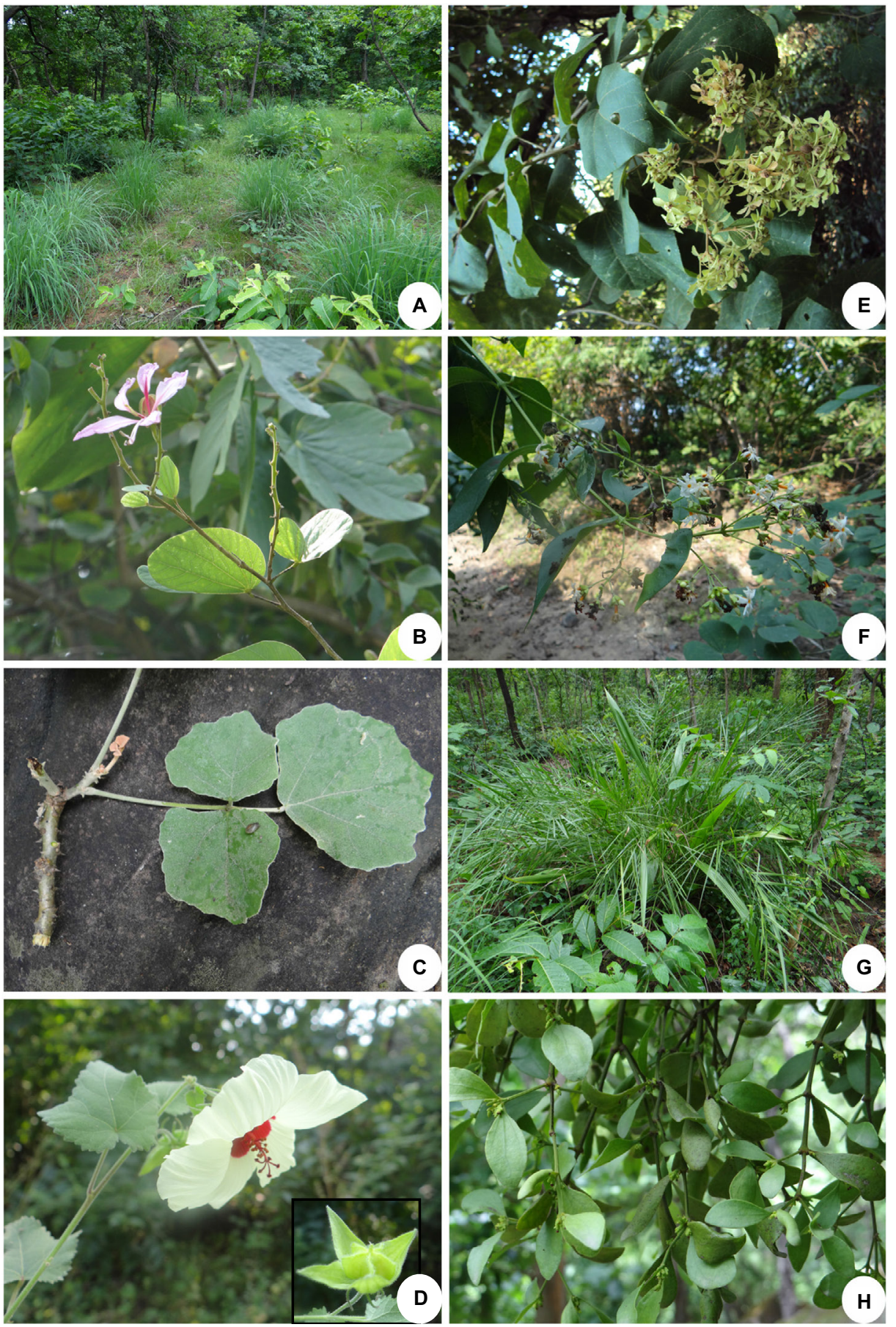

Figure 4 Savannah/grassland and plants of showy flowers. (A) Grassland in the open forest. (B) Bauhinia purpurea. (C) Erythrina suberosa. (D) Hibiscus vitifolius (inset: young fruit). (E) Kydia calycina. (F) Nyctanthes arbor-tristis. (G) Phoenix loureiroi. (H) Viscum cruciatum (stem parasite).

The criteria for informant selection were mentioned in the study by Suthari et al. ${ }^{3}$ The same questions were asked to all informants. Repeated (common or shared; considered here as primary) and unique uses of plant species as mentioned by the informants by the vernacular name or solicited by us showing the plant picture or specimen were noted. The issue of the prior informed consent of the study is available in the paper by Suthari et $\mathrm{l}^{3}$ which presented the intracultural cognizance of Koya community in the area.

\section{Results and discussion Forest type}

It was largely the typical southern dry deciduous forest when it was described by Champion and Seth. ${ }^{19}$ It was in the teak-transition zone. ${ }^{20}$ Now, there is hardly any mature natural teak left due to selective felling by the poachers for its timber. The study area has dry deciduous forest on the hill top (which is unusually flat) and around the hill, moist 
deciduous on the slopes, semievergreen in the valleys and riverine in the streams. The foothill has dry and degraded fire-prone grassland or savannah. Still away is the dry and wetland agriculture or Eucalyptus plantations.

\section{Canopy structure}

The timber species like Anogeissus latifolia, Chloroxylon swietenia, Dalbergia paniculata, Lagerstroemia parviflora, Lannea coromandelica, Tectona grandis, Terminalia alata and Xylia xylocarpa, the multipurpose trees like Mangifera indica and Madhuca longifolia var. latifolia, the economic species like Diospyros melanoxylon and Firmiana simplex and the medicinal species like Boswellia serrata and Soymida febrifuga constitute the top canopy. Acacia leucophloea, Bauhinia racemosa, Cassia fistula, Dendrocalamus strictus and Ficus hispida form the second storey. Ecologically valuable and open canopy species like Cleistanthus collinus, Holarrhena pubescens, Nyctanthes arbor-tristis, Wrightia arborea and Xylia xylocarpa make the third storey. Butea superba is the important liana and indicator species of the undisturbed forests, whereas Gitonia floribunda is the successional species occupying the fringes of the disturbed forest sites.

\section{Flora}

\section{Floral composition}

The vascular plants found represent 470 taxa, representing 318 genera of 95 currently recognized families (Table S1) which are arranged as per Angiosperm Phylogeny Group III, ${ }^{21}$ in a linear sequence. ${ }^{22}$ The species are arranged alphabetically with the accepted scientific names against vernacular name, habit (growth form), life form and the primary use (although other uses known for some, they are not enlisted for want of page space).

\section{Habit}

The plant species, as per their growth forms, are represented largely by herbs $(213 ; 45.3 \%)$, followed by trees $(123$; $26.2 \%)$, climbers $(100 ; 21.3 \%)$ and shrubs $(34 ; 7.2 \%)$.

\section{Nativity}

The plant species are predominantly indigenous and wild $(400 ; 85 \%)$, with the rest $(15 \%)$ represented as naturalized aliens $(62 ; 13.2 \%)$, cultivated $(3 ; 0.64 \%)$ and running wild $(3 ; 0.64 \%)$ and planted $(2 ; 0.42 \%)$.

\section{Life forms}

The range of life forms that have evolutionarily diversified and proliferated in spectacular profusion on planet Earth is unique, and their level of complexity, richness and interrelatedness are ever recorded. ${ }^{23}$ The plant species are categorized into Raunkiaer's life forms, ${ }^{24}$ as modified by Ellenberg and Mueller-Dombois. ${ }^{25}$ The phytoclimate is clearly therophanerophytic ${ }^{26}$ (Table 1). Although the therophytes are great in number in terms of species (Table S1), the vegetation is typically phanerophytic in individual turnover, as per the quadrat study.

\section{The top ten dominant families}

Among the 95 families found on Mallur Gutta, Fabaceae (Leguminosae) predominate with 71 taxa, distantly followed by Malvaceae (31), Asteraceae (19), Rubiaceae and Convolvulaceae (16 each), Amaranthaceae, Acanthaceae and Apocynaceae (15 each), Euphorbiaceae, Lamiaceae and Cyperaceae (14 each), Phyllanthaceae (13), Moraceae (11), Combretaceae and Poaceae (10 each) and Cucurbiataceae (9). The dominant five plant families, in the order of their utility, found for intracultural cognizance study in the Warangal district (Eturnagaram Wildlife Sanctuary and Mallur) ${ }^{3}$ are Fabaceae, Malvaceae, Euphorbiaceae (sensu lato), Rubiaceae and Acanthaceae. We find similarity between the sacred grove and the sanctuary with regard to familywise useful species and the use trend, since the knowledge holders and the beneficiaries in both the habitats are of the same tribe, the Koya. However, Asteraceae is found used more in the sanctuary area which indicates that the area is open for invasive exotics, as reported for the state. ${ }^{26}$ Here, we may say that the sacred grove has much more integrated ecosystem when compared to the Eturnagaram Wildlife Sanctuary, which is under protection as per the Wildlife Protection Act 1972. With their inactions, the Telangana State Forest Department and the Telangana State Biodiversity Board are accountable

Table I Life forms and phytoclimatic spectrum of Mallur Gutta

\begin{tabular}{lc}
\hline Life form & Species constituents, $\mathbf{~}$ \\
\hline Phanerophytes & 150 \\
Megaphanerophytes & 5 \\
Meso-/microphanerophytes & 100 \\
Nanophanerophytes & 30 \\
Stem succulents & 0 \\
Epiphytes & 3 \\
Lianes & 10 \\
Parasites & 2 \\
Chamaephytes & 42 \\
Hemicryptophytes & 52 \\
Cryptophytes & 32 \\
Geophytes & 31 \\
Hydrophytes & 1 \\
Therophytes & 194 \\
\hline
\end{tabular}


for the ecosystem degradation in the Eturnagaram Wildlife Sanctuary.

\section{Rare and interesting species}

The red-listed medicinal plant species like Aegle marmelos, Celastrus paniculatus, Cheilocostus speciosus, Gloriosa superba, Litsea glutinosa, Oroxylum indicum, Smilax perfoliata and Stemona tuberosa and the rare plants like Cordia macleodii, Curcuma inodora, Ehretia laevis, Habenaria roxburghii and Mucuna pruriens var. hirsuta are found in the
Mallur hill range (Figures 4-7). And, Anodendron paniculatum, Dysolobium pilosum, Globba marantina, Flagellaria indica and Paederia foetida (Figures 5A, D, E and G and $6 \mathrm{G}$ ) are so far found by us only in this sacred grove area, and nowhere else in the entire state of Telangana.

\section{Wildlife}

The Mallur hill supports the wild animals like monkey (Macaca mulatta-kothi), Hanuman langur (Presbytis entellus - konda muchu), bison (Bison bison bison-adavi dunna),
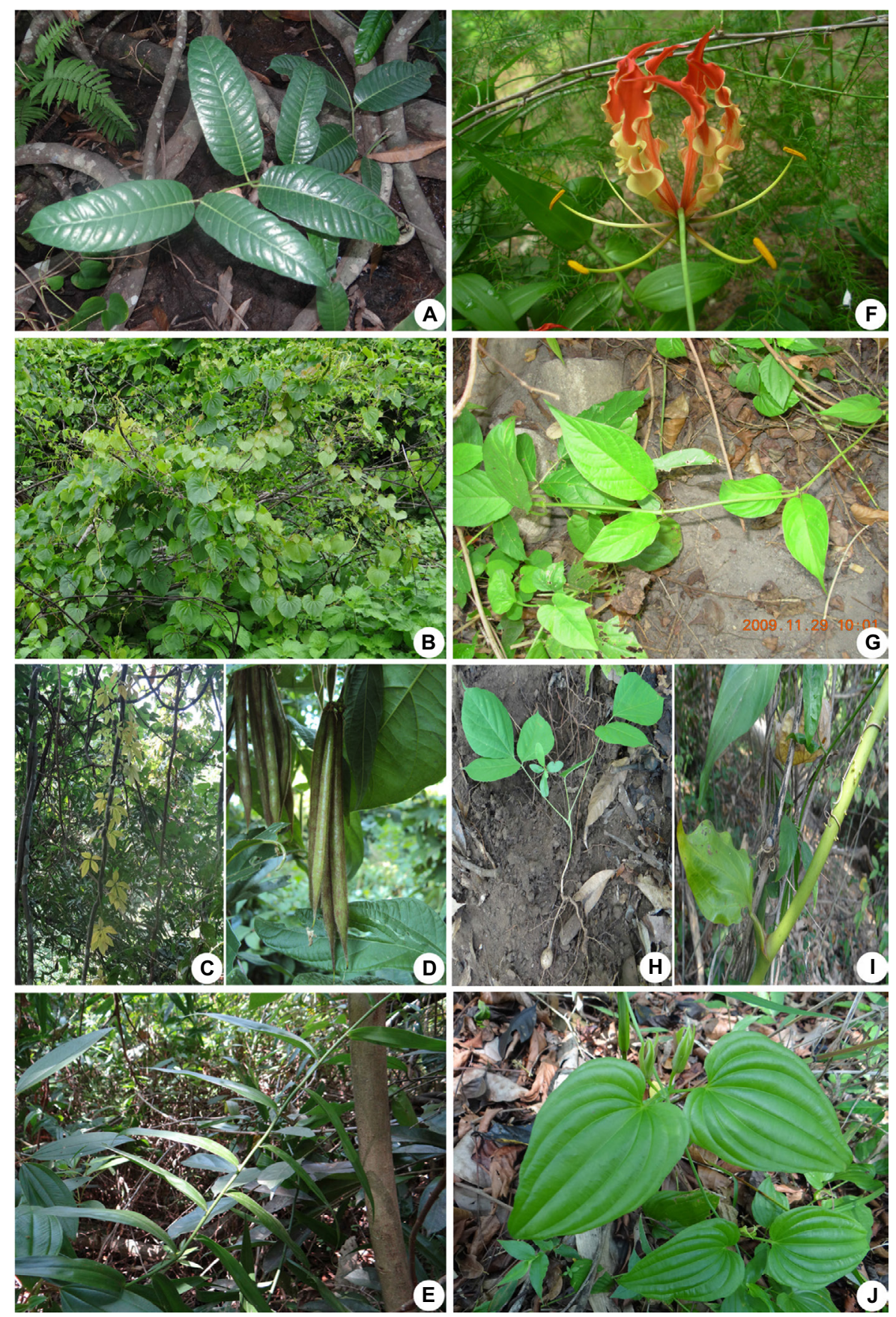

Figure 5 Climbers/geophytes. (A) Anodendron paniculatum. (B) Dioscorea bulbifera. (C) Dioscorea pentaphylla. (D) Dysolobium pilosum. (E) Flagellaria indica. (F) Gloriosa superba. (G) Paederia foetida. (H) Pueraria tuberosa. (I) Smilax perfoliata. (J) Stemona tuberosa. 

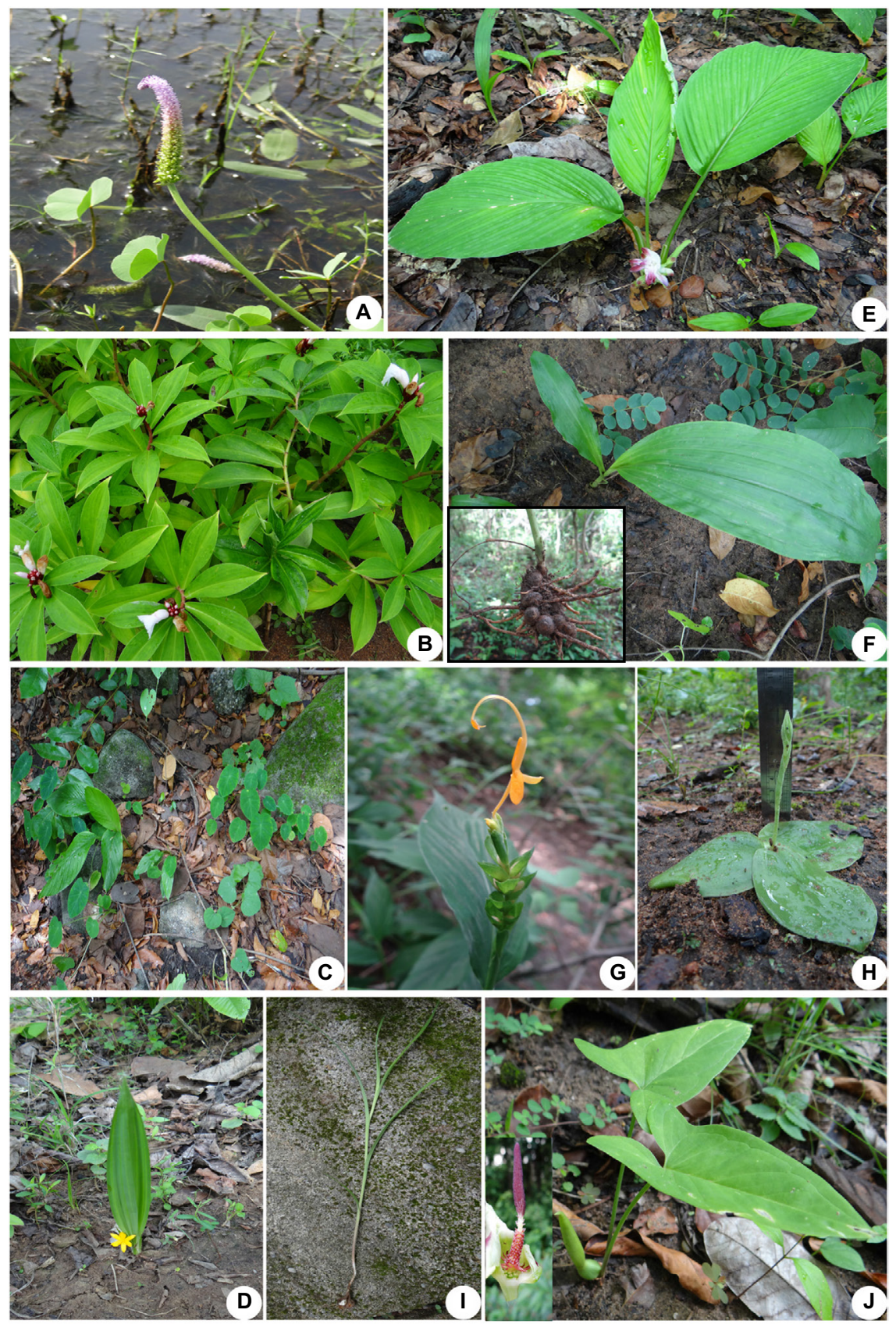

Figure 6 Geophytes. (A) Aponogeton natans. (B) Cheilocostus speciosus. (C) Colocasia esculenta. (D) Cucruligo orchioides. (E) Curcuma inodora. (F) Geodorum densiflorum (inset: bulbs). (G) Globba marantina. (H) Habenaria roxburghii. (I) Iphigenia indica. (J) Theriophonum minutum.

Jungle cat (Felis chauns - jangu pilli), mongoose (Herpestes eddwardsi - mungeesa), wild dog (Cuon alpines - resu kukka), house rat (Rattus rattus rufescens - eluka), fornhorned antelope (Tetracerus quadriconis - konda gorre), nilgai (Boselaphus tragocamelus - manu bothu), spotted deer (Axis axis - podala duppi), wild boar (Sus scrofa adavi pandi, wild pig), three-striped squarrel (Funambulus palmarum - udutha), wild hen, terrapin (Melanochelys trijuga - neeti tabelu), lizard (Calotes verricolor - thonda), forest calotes (Calotes rouxii - adavi thonda), chameleon
(Chamaeleo zeylanicus - usaravelli), monitor lizard (Varanus bengalensis - udumu), dhaman rat snake (Ptyas mucosus jerri pothu), water snake (Xenochrophis piscator - neeti pamu), buff-striped keelback (Amphiesma stolatum - wanapamu) and krait (Bungarus caeruleus - katla pamu) which can be seen in the Eturnagaram Wildlife Sanctuary. ${ }^{8,9,16}$

\section{Ethno- and folk botanical use}

Ethnomedicinal importance of 167 taxa was documented for the Mallur Gutta, Mallur village and the nearby villages 

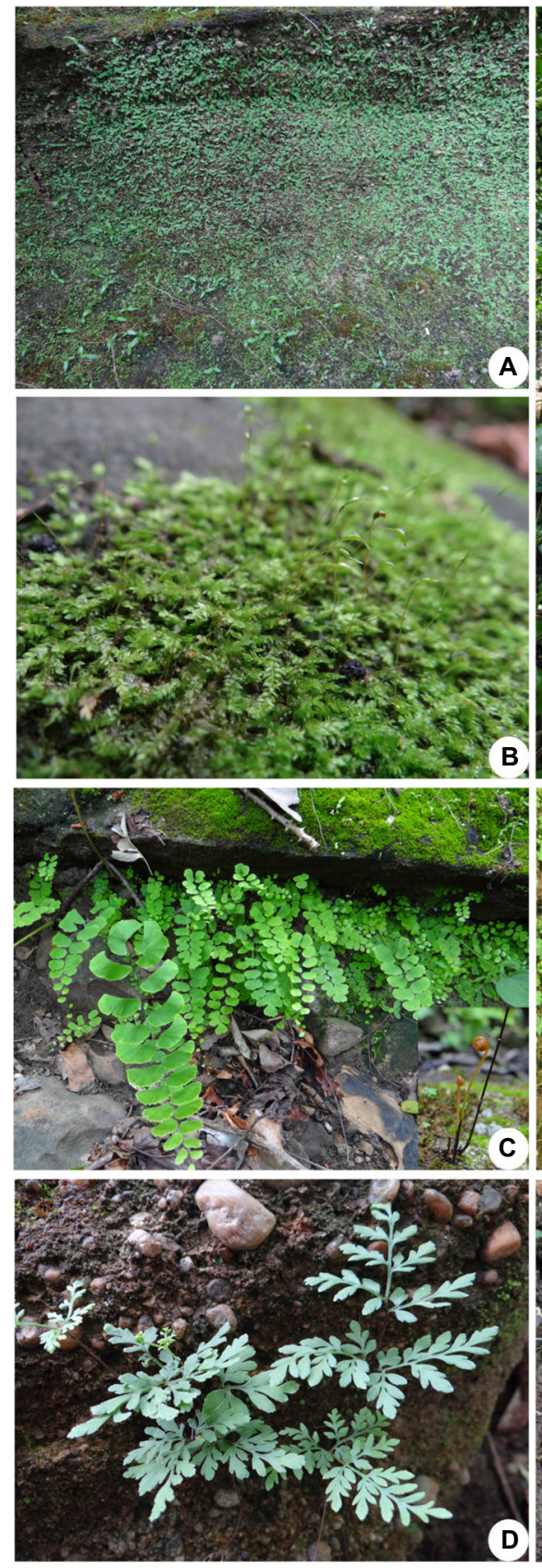

Figure 7 Bryophytes and pteridophytes. (A) Habitat for masses/ferns. (B) Funaria. (C) Adiantum lunulatum. (D) Cyclosorus. (E) Lygodium flexuosum. (F) Marselia quadrifolia. (G) Selaginella involvens.

which are largely inhabited by the ethnic Koya community. ${ }^{3}$ The present study reports many more of these uses by local people; when the uses are listed according to parts of the plants, the leaf dominates the list (23.88\%), followed by the whole plant (15.34\%), root (12.43\%), stem bark (11.46\%), fruit $(10.10 \%)$, etc. (Table 2$)$.

\section{Biotic interference}

The overexploitation of the forest for fuelwood, timber, medicinal plants, etc. is going on unabated with no proper
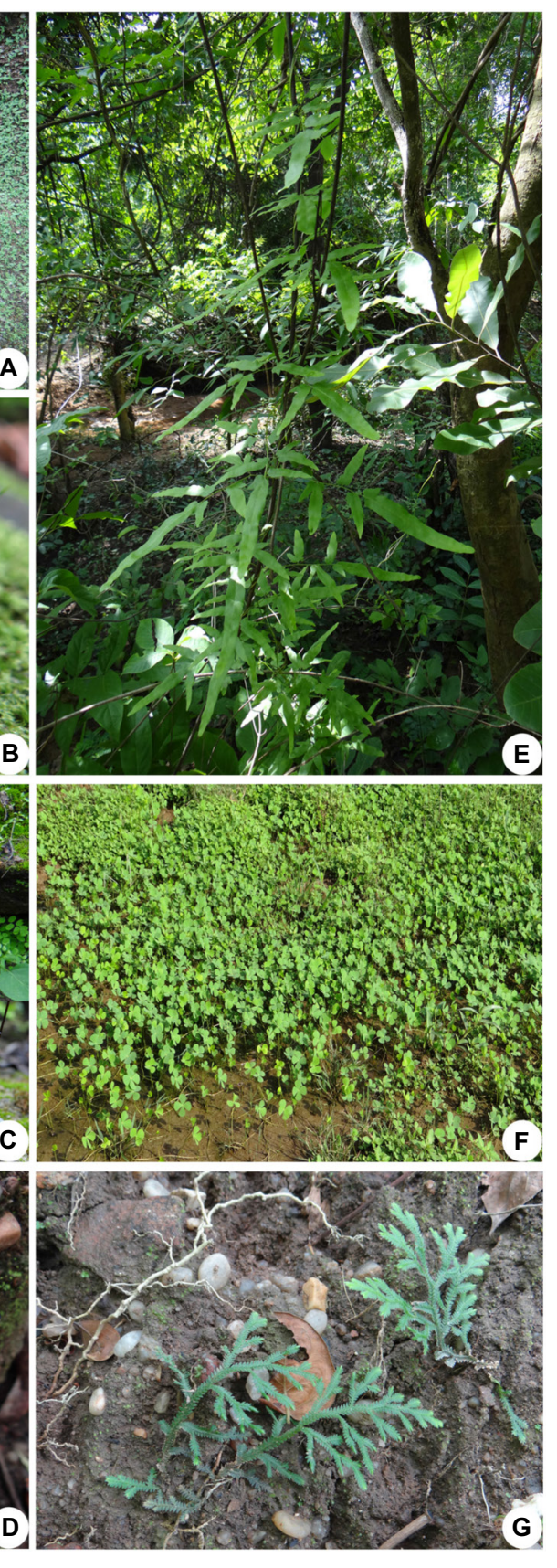

governmental controls. The Mallur VSS which was once active under the Forest Department has become inactive with the scheme lapsed, while there is no continued policy by the assigned and paid protectors of the forests. Human interference during festivals, holidays, Medaram Jatara and Godavari Pushkaralu is a menace to the Mallur forest and its ecosystem integrity (Figure 8E and F). Grazing by cattle, goat and sheep (Figure 8D) is having a devastating effect on the native ground vegetation. The ground is being predisposed to exotic invasives which are on increase both in kinds and 
Table 2 Partwise utility of plant species from Mallur Gutta

\begin{tabular}{ll}
\hline Uses, n (\%) & Plant part \\
\hline I $23(23.88)$ & Leaf \\
$79(15.34)$ & Whole plant \\
$64(12.43)$ & Root \\
$59(11.46)$ & Stem bark \\
$52(10.10)$ & Fruit \\
$33(6.4 I)$ & Wood \\
$21(4.08)$ & Forage \\
I7 (3.30) & Seed \\
I4 (2.72) & Tuber \\
$8(1.55)$ & Rhizome \\
$7(1.36)$ & Flower and fodder \\
$5(0.97)$ & Bulb and latex \\
$4(0.78)$ & Shoot \\
$2(0.39)$ & Kernel, inflorescence, corm, culm \\
I (0.19) & Stem, pseudobulb, branch, leaf bud, \\
& corolla, pseudocarp, fruit pulp \\
\hline
\end{tabular}

numbers. ${ }^{26,27}$ The most threatening ones are Hyptis suaveolens, Chromolaena odorata, Lantana $\times$ aculeata, Prosopis juliflora, Cyanthillium cinereum, Ipomoea fistulosa and Acmella paniculata (Figure 8A-C). Waste food, bottles, meal plates, glasses and such nonbiodegradable items left by pilgrims interfere with biogeochemical cycling.

\section{Conclusion and suggestions}

The present study forms a status report on the phytodiversity, the extent of people-plant interactions and the level of traditional knowledge acquisition, and cognitive ability of the Koyas community of the Mallur Gutta. There are six pointers to be of serious consideration by the managers and the people for the preservation of the cultural, archeological and biodiversity qualities of the Mallur Gutta.

\section{Cultural and botanical heritage site}

The present study clearly demonstrates once again that people and plants coexist for mutual benefit. The temple has a great green setting with the vegetation. The Mallur Gutta ecosystem is to be considered sacred for its natural wealth and primary plant-people linkage and conserved. It may be clearly stated that the forest ecosystem or greenery is preserved not just because there is a temple with a powerful deity (God). The non-tribes just go there for the worship, and for them, the ecosystem services, the greenery and the medicinal plants or animal species present are not precious. There is a need for the revival of MPCA for its past glory, and the Forest Department and the Telangana State Biodiversity Board have to fund the research agencies to monitor the adverse changes in its biota continuously to suggest appropriate corrective measures to conserve it.

\section{Participatory management}

The environment of the sacred grove needs to be protected by an appointed committee with the ethnic people, village panchayat president, VSS members, District Forest Officer, ranger and guard, temple priest and Endowment Department official to frame and implement the measures from time to time for the overall protection of the sacred grove.

\section{Fence}

The hill area should be fenced, or a deep trench is to be dug around the area to prevent illegal occupation of forest land.

\section{Fire lines}

Fire lines should be laid and maintained annually to reduce the incidence and intensity of forest fires during the summer.

\section{Alien invasions}

The incidence of invasion by alien Asteraceae and the ecological implications in the Telangana state are recently assessed and discussed, ${ }^{27}$ and there was a study reporting $C$. odorata as a serious threat to the Eturnagaram Wildlife Sanctuary, ${ }^{28}$ and this weed is also found in the sacred grove area. Action plan for the removal of invasive alien weeds is to be prepared and acted upon as guided by expert taxonomists and ecologists from the Kakatiya University.

\section{Grazing}

Controlling the grazing by goat, sheep and cattle is to be achieved.

\section{Developmental activities}

There must be minimum developmental activity such as erecting building to provide facilities to pilgrims in the sacred grove, but the constructions are to be restricted to the Mallur village only.

\section{Acknowledgments}

The authors thank Dr VK Dadhwal, Director (National Carbon Project), and Dr Sarnam Singh, Deputy Director of Vegetation Carbon Pool Project, Indian Institute of Remote Sensing, Dehradun, UGC, New Delhi, for financial support through a Major Research Project, Dr CS Reddy, ScientistSE, Forestry \& Ecology Division, National Remote Sensing Centre, Hyderabad, for the Remote Sensing map of study area, and Dr V Krishna Reddy, Head, Department of Botany, Kakatiya University, Warangal, for facilities and Mr G 

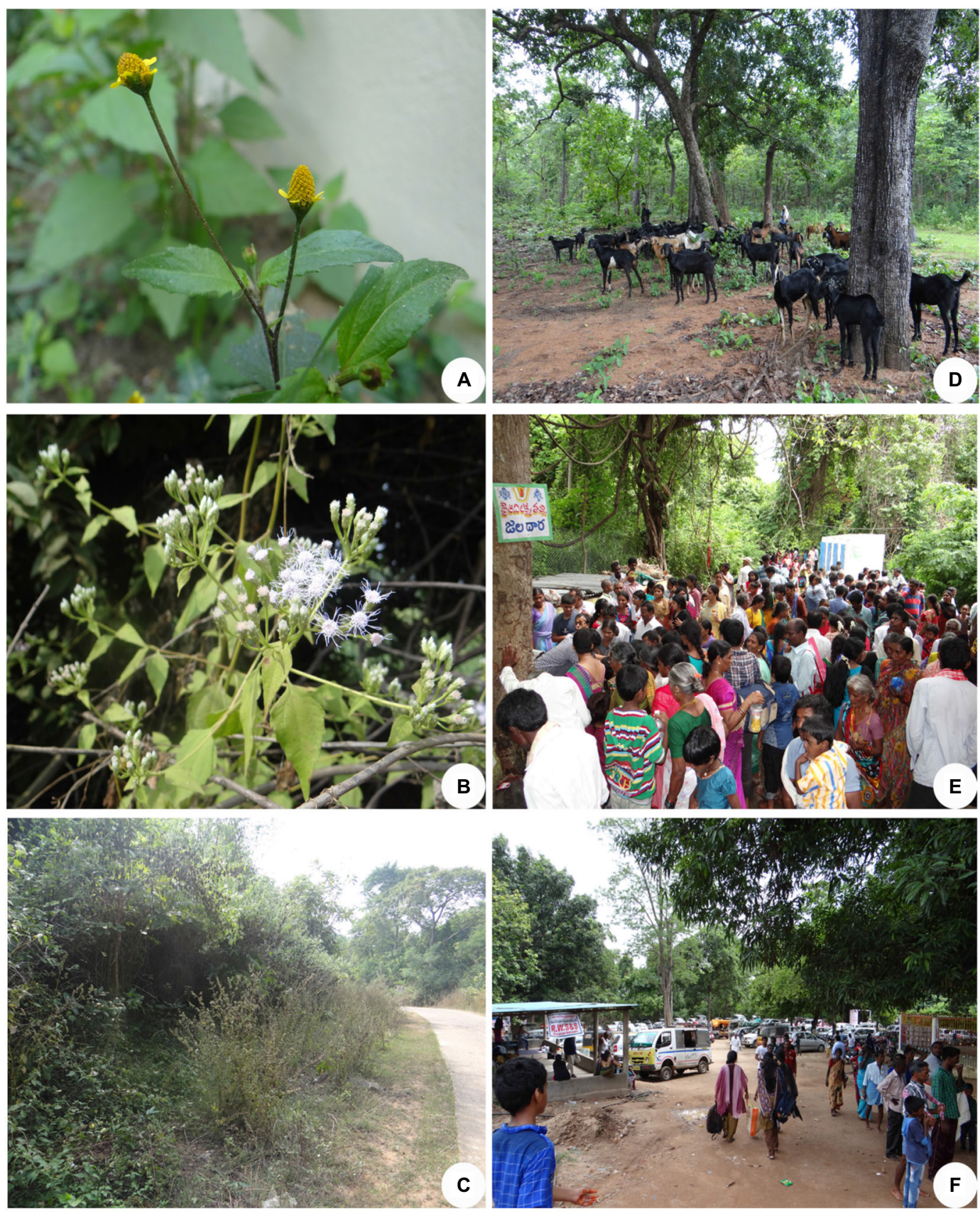

Figure 8 Biotic threats to Mallur hills. (A) Acmella paniculata. (B) Chromolaena odorata. (C) Hyptis suaveolens. (D) Grazing animals on hill top. (E) Pilgrims congregated near Chintamani stream. (F) One of the huge bays for vehicles during Godavari Pushkaram (2015).

Dakshinamurthy for stylistic changes. SS is grateful to Science \& Engineering Research Board, New Delhi, for Start-Up Research Grant (Young Scientists: No. SB/YS/LS-70/2014, dated March 11, 2015).

\section{Disclosure}

The authors report no conflicts of interest in this work.

\section{References}

1. Raju VS, Reddy CS, Suthari S. Flowering plant diversity and endemism in India: an overview. ANU J Nat Sci. 2010;2(1):27-39.
2. Reddy CS. Floristic Studies in Warangal District, Andhra Pradesh, India [Ph.D. thesis]. Warangal: Kakatiya University; 2001.

3. Suthari S, Sreeramulu N, Omkar K, Reddy CS, Raju VS. Intracultural cognizance of medicinal plants of Warangal North Forest Division, northern Telangana, India. Ethnobot Res Appl. 2014;12:211-235.

4. Khan MdS. Forest Flora of Hyderabad State. Hyderabad: Government Press; 1953.

5. Sebastine KM, Henry AN. A contribution to the flora of Pakhal and surrounding regions in Narsampet Taluk, Warangal District, Andhra Pradesh. Bull Bot Surv India. 1996;8:304-311.

6. Reddy CS, Raju VS. Additions to the weed flora of Andhra Pradesh. $J$ Econ Taxon Bot. 2002;26(1):195-198.

7. Reddy CS, Raju VS. Aeschynomene americana L. and Mikania micrantha Kunth - new invasive weeds in flora of Andhra Pradesh. $J$ Econ Taxon Bot. 2009;33(3):540-541. 
8. Gopalkrishna P. Application of Geoinformatics in Vegetation-Ecoystem Analysis in Part of Godavari Valley-Warangal, Andhra Pradesh [Ph.D. thesis]. Warangal: Kakatiya University; 2000.

9. Suthari S. Biodiversity Characterization and Aboveground Vegetation Carbon Pool Assessment in Northern Telangana at Landscape Level Using Geospatial Technique [Ph.D. thesis]. Warangal: Kakatiya University; 2013.

10. Sateesh S, Raju VS. Antidote botanicals for snake bites from Koyas of Warangal district, Telangana, India. J Herbs Spices Med Plants. 2016;22(1):57-68.

11. Raju VS. Warangal. In: Sacred and Protected Groves of Andhra Pradesh. Hyderabad: World Wide Fund for Nature, Andhra Pradesh State Office; 1996:85.

12. Reddy CS, Reddy KN, Jadhav SN. Threatened (Medicinal) Plants of Andhra Pradesh. Hyderabad: Environment Protection Training and Research Institute (EPTRI); 2001.

13. Oviedo G, Jeanreneud S, Otegui M. Protecting Sacred Natural Sites of Indigenous and Traditional Peoples: An IUCN Perspective. Switzerland: Gland; 2005.

14. Malhotra KC, Gokhale Y, Chatterjee S, Srivastava S. Cultural and Ecological Dimensions of Sacred Groves in India. New Delhi: Indian National Science Academy; 2001.

15. Kulkarni YR, Sangode SJ, Meshram DC, Patil SK, Dutt Y. Mineral magnetic characterization of the Godavari river sediments: implications to Deccan basalt weathering. J Geol Soc India. 2014;83:376-384.

16. Nagulu V, Rao VV, Srinivasulu C. Biodiversity of select habitats in Eastern Ghat regions of Andhra Pradesh. In: Proceedings of National Seminar on Conservation of Eastern Ghats. Hyderabad: Environment Protection Training and Research Institute (EPTRI); 1998:6-35.

17. Dubey KC. The Dorlas of Bhopalpatnam, Bastar district. Bull Tribal Res Training Inst Bhopal. 1970;8(2):1-12.
18. Thiers B. Index Herbariorum: a global directory of public herbaria and associated staff. New York Botanical Garden's Virtual Herbarium. Available from: http://sweetgum.nybg.org/science/ih/.Accessed May 15, 2014.

19. Champion HG, Seth SK. A Revised Survey of the Forest Types of India. New Delhi: Government Press; 1968.

20. Meher-Homji VM. Tropical dry deciduous forests of Peninsular India. Feddes Rep. 1977;88(1-2):113-134.

21. APG (Angiosperm Phylogeny Group) III. An update of the Angiosperm Phylogeny Group classification for the orders and families of flowering plants: APG III. Bot J Linn Soc. 2009;161(2):105-121.

22. Haston E, Richardson JE, Stevens PF, Chase MW, Harris DJ. The Linear Angiosperm Phylogeny Group (LAPG) III: a linear sequence of the families in APG III. Bot J Linn Soc. 2009;161(2):128-131.

23. Lane DJW. Biodiversity: crises past and present and future challenges. Res Rep Biodiversity Stud. 2011;1:1-2.

24. Raunkiaer C. The Life Forms of Plants and Statistical Plant Geography. Oxford: Clarendon Press; 1934

25. Ellenberg H, Mueller-Dombois D. A key to Raunkiaer plant life forms with revised subdivisions. Ber Geobot Inst Eidgenöss Tech Hochsch Stift Rübel. 2015;37(1965-1966):56-73.

26. Raju VS, Gopalkrishna P, Suthari S. Environment assessment of climate of a habitat through floristic life-form spectra, a case study of Warangal North Forest Division, Telangana, India. J Nat Sci. 2014;2(1):77-93.

27. Suthari S, Ramesh K, Ragan A, Raju VS. Incidence of alien Asteraceae in Telangana and residual Andhra Pradesh and ecological implications. Curr Sci. 2016;110(7):1337-1343.

28. Sateesh S, Ramesh K, Geetha S, Ragan A, Raju VS. Intrusion of devil weed, Chromolaena odorata, an exotic invasive, into Kinnerasani and Eturnagaram wildlife sanctuaries, Telangana, India. J Threat Taxa. 2016; $8(2): 8538-8540$.
International Journal of General Medicine

\section{Publish your work in this journal}

The International Journal of General Medicine is an international, peer-reviewed open-access journal that focuses on general and internal medicine, pathogenesis, epidemiology, diagnosis, monitoring and treatment protocols. The journal is characterized by the rapid reporting of reviews, original research and clinical studies across all disease areas.

\section{Dovepress}

The manuscript management system is completely online and includes a very quick and fair peer-review system, which is all easy to use. Visit http://www.dovepress.com/testimonials.php to read real quotes from published authors.

Submit your manuscript here: https://www.dovepress.com/international-journal-of-general-medicine-journal 